\title{
Review Essay on Asian Security Discourse for the New Millennium:
}

\section{On the Perspective of the Korean Peninsula"}

\author{
IHNHWI PARK \\ Department of Palitical Sizence. SungKyunKuan Unizersity
}

In East Asict. four issues center on the discussion of security in the next century. The first one is associated with the significant long-term changes in the equations of military and economic pouer and the general frameturk of regimal security in the region. Secondly, the underdeveloped institutionalim wours not because of "culture" per se, but because of different ways of thinking. The problem bas to do with the security of Asia as a region, not Asian seiwit). Thirally, despite Asianization and vastly divergent interests acriss East Asian cotntries, one common view that seems to be whared by all regional siates is the Unitat States security ommitment at the indispensable ancber for East Asian security. The latit tisue includes tuw interdependent topics, the Korve-U.S. welations and North Korta. The updating of the Korea-U,S, relations should start from the following two important aptratabes to the alliance countries: 1) the difference in secarisy iomeption of the two countries, and 2) prefaring eath state's

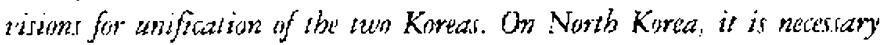
to acknoledge the Nonth as a state alicnated from the international. order: uitich is dominated by the U.S.

\footnotetext{
* The original version of this paper was presented at the 1999 Annual Conference of che laternational Sccuricy Studies of ISA, Washington, D.C. in November lyyg.

I am especially graceful to Stephen Gilbert, Tong Whan Park, and two anonymous referees of the Intumationai Sindes Revieu for their insightínl comments.

Direc ali correspondence to Ihnhwi Park, Jecturer, Depastment of Political Science, SungKynaKwan I niversicy, 53 3lyungryundong 3-ga, (hongro-gu. Seoul, 110-745. Korea, or Farnily Apt (104-901, Munjung-dong. Sormprätru. Stonl, 138-202, Korea.
} 
A nother century is approaching, and this tirne it comes with a very special label, A"a new millenrium. "Many scholars and andysts argue that "security" in Asia proposes an intrinsic instability in the twenty-first century and that is exists theyond our reach. "Security" is a very social construct. It comes into being at a specific time and in response to a specific st of circumstances. Therefore, we need to decode a security function in terms of the Asian context before pessimistic assumptions dominate our views on Asian securicy. Is Asia ceady to enbrace a new security discoutse for the new millennium? The paper's purpose helps us think about this question.

The cad of the Cold War brought about fundamental shifts in the nature of international security:- The result is an emergence of a tonafide regional security complex, wherein state security perceptions and concerns are the functions of regional interstate interactions to such an extent that the state's security intercsts are dosely tied to one another. In Barry Buzan's words, "The formarive dynamics and structure of a security complex are gencrated by the staces within the region- by their security perception of, and interactions with, each other." 2 These affect both the form, the means of warfarc, and the meaning of security itself. It is a natural realization that discussions on Asian security center on these new discourses of international security. Since every subject in Asia about security is tightly intertwined together, one cannor separate security from the economic, social, and cultural facts of the region.

The systeratic approaches to Asian security have been addressed in che current security discussion without much satisfactory clasification, although their significance have bets ever salient in the post-Cold War era. After the end of the Cold War, whenever we discuss Asian security, ${ }^{3}$ we only focus on Asian security either as a whole without specific considerations for the specific regions at issue, or in terms of the U.S. perspective toward edch Asian individual state. Or, sometimes, certain groups of people prefer to deal with the problem with the laliel, "Asian Way." Therefore, we have been naturally familiarized with certain typical questions such as, "how do che proponents of neo-liberal institurionalism explain the Association of Southeast Asian Nations (ASEAN)?"; "should the li.S. now intensify efforts of draw Japan into what the two governments hate described as a global pitenership to contain a Chinese threat?"; or "how much can an Asian culture or civilization tell us about Asian security?" Each question does nor fully answer the main problems that Asian security has encountered after the end of the Cold War. In each question. one perspective has been taken, and it tends to highlight some features

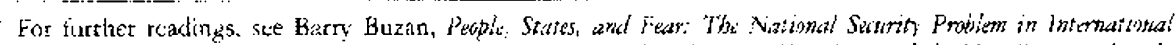

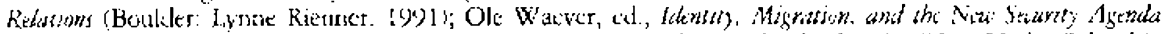
I" Eampe (Tondkn: Piocer Pubishers, 1953): Ronnic D. Lipschutz ed., On Secority (Now York: Columbia

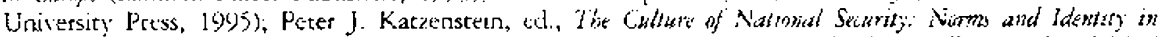

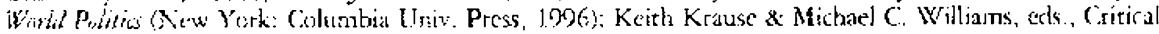
Security Studies (Ming

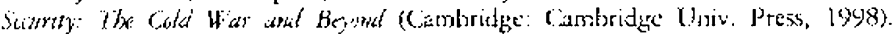

Barry Buzan. "The Post-Cold War Asia-Pacific Security Oriler: Contlict or Couperation?" In Pactiti Cosperation:

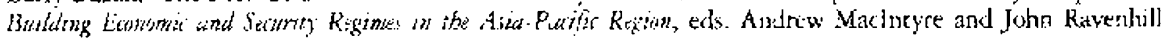
(Houliter: Westriew Press, 19\%5), p. !3]

Asta covered by the term and the divessity within that area is great. The distance from Tokyo to jakartas

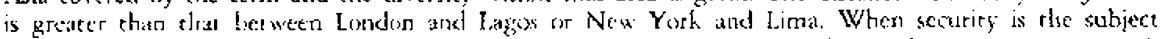
andet discussion, ir is particularly televanr to keep such distance in mind. For this paper, East Asia is under considetacion fot discussion. Whah includes Northedst and Siltetheast Asia. 
of the object under scrutiny but suppresses others.

Throughout this paper, 1 do not intend to present any designated policy options for any specific countries, or any newly designed theorctical framework to interpret the current security problems in the area. Rather, I would like to demonstrate a cleat and comprehensive outlook of Asian security in which four positions are presented here; security complex of economic and military dimensions in the region, a debate on Asian W'ay and the underdevelopment of institutionalism, the U.S. presence in the region as a power balancer, and finally, the obsolece relationship betwcen Korea and the LiS. Then, to handle those difficulties, a suggestion to overcome the virtual absence of effective Asian multilareralism will be introduced.

\section{POST-COLD WAR AND ASIAN SECURJ'TY}

\section{The Meaning of the Past-Cold War Era in Asia}

Like the rise of the middle class as we study history, the end of the Cold War risks becoming an all-purpose explanation. As Fernand Braudel has demonstrated, while culcure can change fairly rapidly, there are basic determinants of "civilizacion" that change only very slowly if at all." following this view, the emergence and decline of the Cold Wat are the most primary dominant determinants in sccurity discourses during the twentieth century. The sudden collapse of the Soviet Empire in 1991 and the following end of the Cold War havecaused significant long-termctanges in the equations of ruilitary/economic power, and the general framework of regional security in Asia as well as the rest of the world, notably Europe. Can the nations of the region define a satisfactory franework for interstate relacions in pursuit of its separate national interests withour inducing destabilizing geopolitical realignments or overt military hostilities?

The end of the Cold War has, on the one hand, substantially Iessened ideological and milicary tensions and heightened hopes for cooperation between esstwhile adversaries of the Cold War period. On the other hand, it has sharpened conomic and military (though lesser in extenr) competition among erstwhile allits and friends during that period. However, as far as the physical or structural aspects of the region's security environment are taken into account, the changes have been hardly as dramaric as one mighe have expected so) far. This happened because the cold War had two dimensions-che settemene at Yalta and the ideological contest between the. United States and the Sovict Union-sacther of which had any contemporary relevance for the Asia-Pacific.;

The Cold War neicher posed a barrier to the choices facing the states of the Asia-Pacific

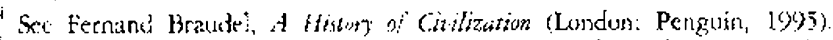

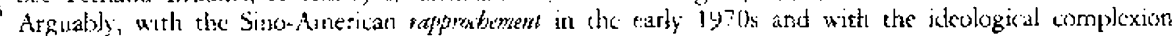
if Asian countries, the Yalra setrlement hat no apprecialste impact on the foreign policy calculations if either the Liniced States or the Societ Union in Asia. 'To the contrary, as John Lewis Gaddis has

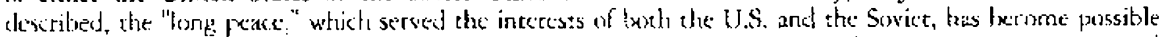
an Eureje. Yalta prevented eicher state from establishing hegemony ove: the Eutopean continent and inasieted cach pawer wich an extendeci detconse parimeter.
} 
nor fundamentally affected how states interpretcd or acted upon the underlying structurat conditions shaping regional or sub-regional balances of power and interests." Unlike. the Europein case, the end of the Cold War in 1989 did not initiate a change in the systematic context that unleashed the denand for the institutionalization of security or economic relationships.

However, the Cold War still has a historical significance in Asia. Above all, the end of the insurgencies, ot the marker of the Cold War, has left Asia with a structure of consolidated nation-stares with mostly srable political institutions and stable borders. In the twentieth century, nation-building was the first task for chose states that emerged from colonialism, and after a generation or more, national identities seemed secure. As always, there axe still plenty of loose ends, cthnic and religious differences, as well as overlapping territoriat claims. Nonetheless, while the economic dynamism continues, the foundations are firm and, likely to remain stable. Indecd, the economic achievements due to the Cold War have understandably given the region's loaders great confidence in the futurc. East $x$ sian countries were experiencing a rapid economic groweth during the Cold War. Their confidence for the furure and their nacional identity were consolidated as a result. This experience has been a key dercrminans sign of stability in the region.

It is also true that international politics is event-driven, and that the region's resilience and stability have not been tested by a major challenge against the present equilibrium or by an outright crisis that undermines the status guo. Amid optimism about the region's extraordinary dyramisin, decerer anxieties persist regarding the sustainability of the existing balance of power. Therefore, in the future, these signs of stability may be misleading. Beneath a veneer of shared interests, there loxm deeper differences and potential incomparibilities broughe with the end of the Cold War that defy a ready resolucion. Although Asia, mostly East Asian councries to be exact, has achieved a momentous prosperity unimaginable several decades ago, the transition toward a more autonomous and powertul region is uneven, incomplece, and replete with uncertainty. As a consequence, the outlines of at more durable security order ine barcly discrnible at present. Indecel, rather than guarantecing a peaceful or stable regional system, East Asia's political and economic emergence could generate new partems of comperition and conflicrs that will shape some of the principal contours of the international system into the next century.

\section{Security Complex of Military and Economic Dimensions}

The astonishing economic dynamism of the tegion is bringing with it a growing interdependence. Distances are shrinkingt and cach of their economies is bccoming more dependent on the wetl-being of the orhers. There is a security aspext to this new sense of regionalism. If we increasingly share a common destiny, then we will increasingly share common security concerns as well. Interdependence may reduce the risks of any

"On the contrary, the Cold War provided an imernational context that acted as a barsiter ro change in

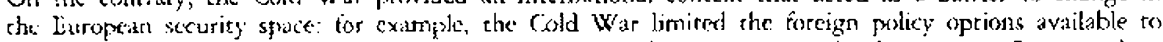
the central and eastern European scates; Poland. Cacchoslowakia, Hungary, and other Warsaw Pacr members

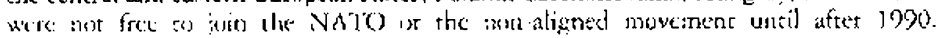


serious troubles. In other words, any troubles that might erupt will no longer be isolated from each other.

The major limitations of Asian regional security seem fairly straightorward. The differences in power among different nation-states, unresolved historical issues, the existence of latgely autonomous cultures unaccustomed to long-term habits of association and interaction with their neighbors, and the extraordinarily rapid economic and social change in the recens years have all constrained the development of a more mature and institutionalized regional order. The Korean peninsula, especially, neods to pay greater attention to thesc factors than any other country in the region. 7 Korea symbolizes the securiry confrontation of the post-Cold War world that is unfamiliar and troublesome for national policymakers. It focuses morc on the interconnections between the economic and military dimensions of security which, in turn, makes the national calculus of costs and benefits more complicated and ambiguous. The proposition suggests that any future security order in Asia, especially in the Korcan peninsula, will possess at least two mutually constitutive and intetdependent dements, namely, the political-military and the conomic.s

Korea and other East Asian countries' current econonic crisis made them realize that the economic dimension of security has three identifiable and separate elements. First, economic security reflects a concen over the ability of the state to prorect the social and economic fabric of at society. Second, economic security involves the ability of a state to act ats an effective gatekeeper and to mantait societal integrity. Lastly, economic sccurity concerns the ability of the state in cooperarion with others to foster a stable international economic environment in order to reinforce cooperation in the military sector as well as to extract the welfare gains of openness. However, all these elements are closely associated with sensicive subjects like "sovercignty." These are the security conceprions of the cold War era which are no longer applicable in the next century. This is because most of the East Asian states have approached the issue of economic security as a strategic one in which any kind of external threat is identified ats a threat to a nation-state's "sovereignty."

Therefore, a comprehensive exploration of the regional security syscems in Asia cannot dodge the problem of economic securicy or treat the economic factor as an instrumental adjunct to the military requirements of security. Nor can we be satisfied with simply displacing the military definition of security with an economic conceptualization of security, for the military dinersion rcmains too important, particularly in East Asia. According to realist argument, the break-up of the superpower overlay allows, and indeed compels local patterus of amity, enmity, and balance of power to reassert themsclves. The security requirements of Asia in the new century semand a broader, systematic definition of the relationship between economic and military dimensions of security. It also suggests that an analysis of the security conceptions of Asia must be framed not only by these

Jomathan 1). Pollack advecates this pexition lecausc," ". all states in the region have an obvious incentave to work ccedibly with one unother on the Korcan problem, as none would be immune the potcontial

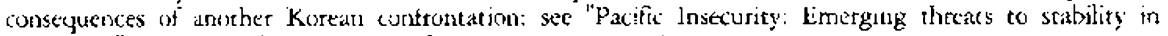

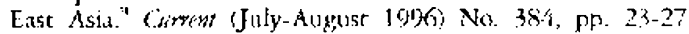

"Buzatr was nusst significant on this apperach in the pose-Cold War ea. See Bary Buzan, Perph. States,

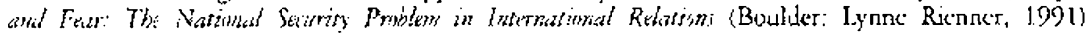


(wo components of security alune, but also by how thesc two elements of sccurity interact and the consequences of such interaction formulate a stable security oreter.

One typical concern of Asian instatility is the increase in military expenditures in most Asian countries. States in the region are responding to the uncertainty of future thredts, their rapidly expanding economic strength, and the diminishing security commitments of the supespowers. In many cases, they are purchasing state-of-the-art missiles; aircratts, and warships from the United States, Russia, Furope, and other arms exporters. Of course, there is no evidence that any Asian nation is strengthening its armed forces in anticipation of going to was. Most analysts believe that $\Lambda$ sian nations are mudernizing their military for defensive purposes. Nevertheless, in contrast to other regions in the world, the Asian region is experiencing an arms buildup, which, at the very least, suggests that nations in the area feel insecure atout their neighbors-the traditional realistic security dilemma. Thus, the phenomenal rates of economic growth experienced by the East Asian states suggest a shift of the economic balance of power in Asia's favor for cuncurrent weapons modernization programs with a relative dectine in the military-strategic capabilities of the Lnited States and the other powers. Interestingly enough, these trends, which appear inexorable, but remain contested, could produce a balated Asia that reproflues the Furopean experience of the postwar periof. Or, it could reproduce the Eutopean expericne of the interwar period.

\section{DOES THE ASIAN WAY REALLY MA'T'TER?}

\section{Asian Way as Myth?}

Regional stability in Asra is possibte in the next contury, if the region is able to expand its economic development for security space. The optimises do not deny the risks in the region, but they do suggest that the deprh and complexity of economic interdependence among the states make the outbreak of the war very unlikcly. This argument stems from the liberal views on how the international political economy opcrates." Several questions follow this axiom. Why is institutional interdependence so underdeveloped In Asta? Does the Asian way, or $\Lambda$ sian identicy, matter in the devclopment of insritutionalization? Then, bow do we explain the recent conomic difficulties of East Asian countries in terms of "Asian way?"

Those counter views on the Asian "myth" generally argue that the attempt to thetorize Asianism is basically an expression of "inverted oricntalism," which is the East Asian tendency to identify the "West" in antithesis to the "East." "This state-sponsored discourse of uniqueness is no more than a self-serving act of Asian elites to legitimize theis patriarchal

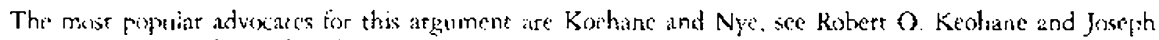

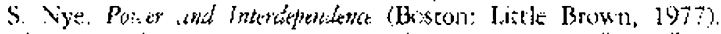

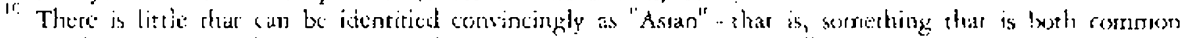
to all or mose of the cuunctes and socitetes of that region and different form what prevals oucsick che reg:en. 
rule, "crony capiralism," of "neomercantilist behavior." II Since the latest financial crisis began in the region in the summer of 1997, many Western critics have been quick to claim the bankruptcy of the Asian model and the victory of Anglo-American liberal denocracy and latisez-faire capitalism in the paradigmatic rivalry dating back to the early 1980s. I Untortunately, this is a misperception.

Obsetving the recent economic difficultes in Fast Asia in terms of the paradigmatic conflict as they are rooted in real interest, power, and culture, I belicve the tendency of Asianization may retreat but will not go axay. Within this vein, Johnson's point is well taken. ${ }^{2}$ Indeed, it could gain momentum if mishandling of the crisis leads to stronger anti-Western nationalisn and greacer regional solidarity. Movements of Asianization should not be rejected lightly just because of the Asian clites' self-serving inclination to rhetorize Asianism. Oree needs to move beyond the discourse centering arcuad some cultural givens and traditions in order to look at other non-cultural dynamics of Asianization.

Unlike the claims made by some advocares of an Asian sray, the discourses of East Asian regional security are not primarily concerned with defining the substantive values of a regional commutity and how best to procect them. More ambitious, and universal clains of an Asian way amount wo a recipe for the conversion of Western "literal" states. This prospect may be ol" some appeal to couservatives fearful of disintegrarion and moral decay in what they see as their own ill-disciplined societies, but it has not attracted much support in liberal-democratic quarters of the West. The values associated with an Asian way are therefore of little intrinsic significance to regional security discourse beyond their location within the existing nation-states. Kather, the major concern is low an Asian way functions as an operational or procedural code in shaping regional security and strategic issues.

As we have wirnessed, current economic difficultits in the region have not diminished the importance of sccurity at all. Rather, these difficulties have increased their weight in world affairs, and they suggest the possibility of Asia finding a new, distinctive (and, by implication, superior) Asian way of coping with global, political, and social issues, including those arising from security concerns. Multilateralism or insticutional interelependence is necessaty for the continuity of stable economic development and its successfu] expansion to the security realm itr the next cencury.

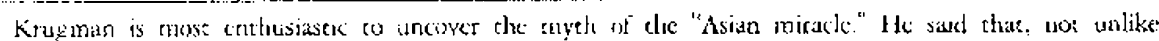
the now-repudiated Sralinise Sovice economy, it beurdes co stagnate following an early spuse of growth prompted by vist inguse of physical resureces. Thus, the model is of "pxrspication rather than inspiraciem." Sce Palul Kruginars. "The Myth of Asia's Misacle." Estrign iffisirs, Fol. 73, No. 6. pp. 62-78.

1. For :nstance. Robet Wase provides a fascinating account of the dash between the Asian and model

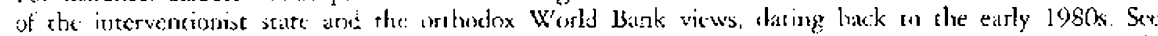
Rolbirt Wadt. "Japan, the World Bank, and the Arc of Paratigm Madintenance: The Eist Asian Miracle

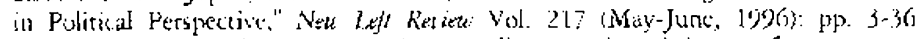

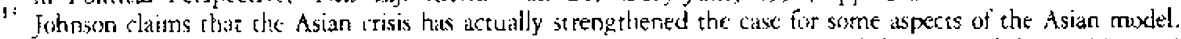

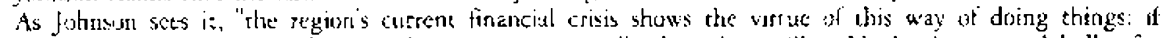

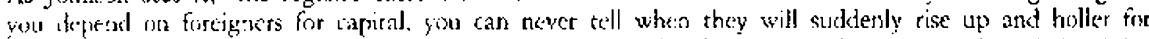
repayments. The lesson: is to retouble aterotion io the atitarky that is tenttal to one version of the Astan

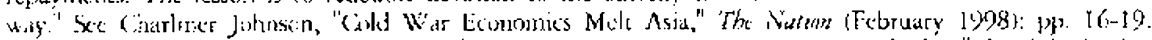

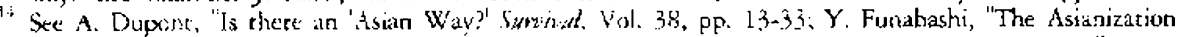

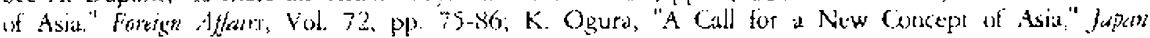

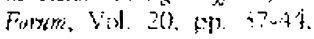




\title{
Institutional Interdependence and Ariun Culture
}

\author{
Kissinger, a prominent American diplomat, once noted:
}

"Whereas the nations of Europe are grouped in common insticutions, the narions of Asia viex themselves as distinct and competitive. The relacions of the principal Asian nations to each other bear most of the attributes of the European balance-of-power system of the nineteenth century... ":s

The role ascribect $t o$ incernational institurions ranges from those analysts who view international institutions as the foundation of international societyl' to those who dismiss international instizutions as the expressions of state power ${ }^{17}$ or as insignificant determinants of state action as compared to the unclerlying structure of power. 1 . Following these theotetical configurations, it is difficult to prescribe the degree of Asian institutional development within these three roles since Asian institutionalism is still at the very beginning stage. In Asia, as Richard Betrs notes, "the leap from economic multilateralism to multilateral security planning is not yet in sight." 19 Indeed, "threats to security in East Asia come from a lack of an effective regional security mechanism to manage new sources of instability unleashed by regionalization,"20

Then, this question arises: Why is the level of multilateralization of security's economic and military dimonsions so underdeveloped in $\Lambda$ sia? 21 'There are a number of explanations, but three explanations are most prominent: the asymmetry in the evolution of the European and Asian nation-states ${ }^{22}$, the context of international politics in the Asia-Pacific that compels states to focus on telative rather than absolute gains in the calculation of state policy, ${ }^{23}$ and the cultural barriers to collective identity formation and the consecuent

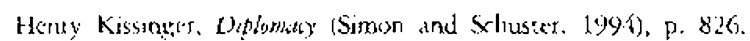

Scholars such as Buil, Keobane fall into this group: see Hedky Bull, The Arathocal Soxicy (New York:

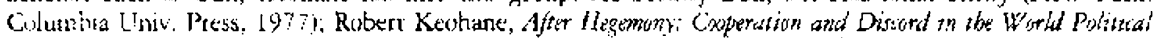
Fonmme (Prinicem: Princecon (InIv. Press, 1984): Keohane and I isa Martin, "The Promise of Institutiona]

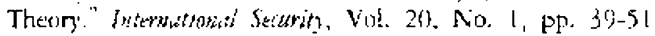

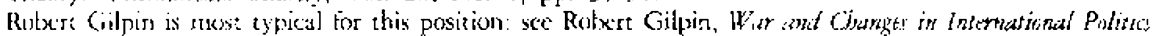
(Princesun: Princeeon Liviv. Press, 1981\%.

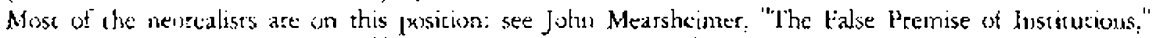

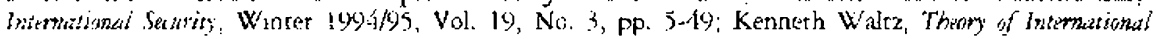
Pulno (Kerding, Mass: Addison-Wesley, 1979).

$\Rightarrow$ Rethard Betes," W'ealth, Power, and Inscability: East Asia and the United Scares aftes che Cold War," Intimational Securit). Vol, 18, No. ?, p. ?2.

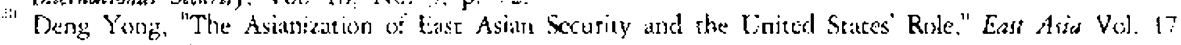
(Autumin 1998: p. S?.

Linquestiotiably, there are late developments of insciturionalization in Asia. it was uine years ago (1990) APFC. was established. It has not unly chareered a pach for the development of regional free trade, it has aiso growth into an annual summit of the eggions leaders. Four years later the ASFAN Regional Forum (AKF) was creaced is a means of consulting about the region's security interests.

$\therefore$ Fricdberg argues that the European nation-state building and the Asian nation-state are at different stages of evolution: the Europxin state is increasingly charaterized by an (rosion of suvereignty and growing economic interdependence; and by the need if national atuhorizies to consolidace and sustain intema]

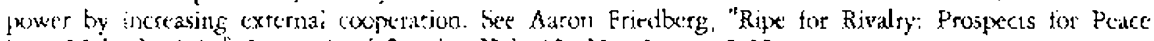
in a Multiple Asia," Intemasinnal Securing, Vo]. 18. No. 3, p[3. 5-33.

$A$ core issue of the neorealise-necoliberalist debate ceuters on the assitiptions about the state preferences. 'The nel'realist scheol assianes that states are relative gains maximizers, and the neoliberal insejeutionalist school ussumes that states are absolute gains maximizers. Powell hisis argued that preferences are nor

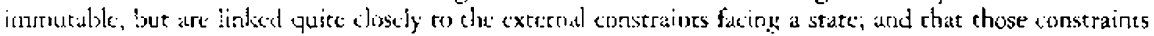


impaiment of international cooperation and institution-building.

Wendt's proposition draws our attention to the perspective of the last explanation with regard to this paper. ${ }^{24}$ Borrowing his explanation on collective identiry, the relatively low level of insticutionalized cooperation among Asian countries is due to the absence of an emergent collective identity in Asia. "This factor bears dircely on the debate generatcd by Huntington's hypothesis that the root cause of future international contlicts will bx located in a dash of civilizations. .5 Wencle argues that one solution to the problem of collective action -nat motor propelling the institutionalized cooperation in the European security space--is located in the process of collective identity formation, which has arguably axcurred in Europe and is at an embryonic state in the Asia-Pacific. ${ }^{26}$

Huntington's argument centers on this discussion. His proposition may be the most frequently discussed topic in the second half of the twonticth century with the exception of George Keman's "contamment" piece. Of course, Huntington's empbasis on the importance of civilizational contlica has been roundly criticized as being unable to account for the shift in toyalty from the state to civilization, or to demonstrate that such a shift has taken place, since he ignores the continuing force of nationalism. He has also bcen criticized for suggescing that Western values have only a specific rather than an universal legitimacy. Yet, Huntington does redraw our attention to the existence of civilizations and the importance of difference and force ourselves to consider whether that differcnee plays a cole in the shaping of state preferences. His argument is important because it provides a cluc to this question: What are the barriers to collective identity formarion in Asta? From the security standpoint, civilizational differences in Asia produre divergent intersubjective strucrures that generate antagonistic interpretarions of the material balance of power.

Here we come to the deepest layer of risks to our future well-being. "Culture" sliould not moan Asian values or even cultural sensitivity (those things that the guidebooks tell you, whe as not spitting on your host's floor or patting the heads of his children). Rather, it should mean that societies with different traditions will tend to see a common problem in different ways. This happens not only in Asia, but also in the Western world. Cultural isolation is the carbon monoxide poisoning of incernational relations, deadly, yet, so insidious that the players are often unaware of its effects on their judgement. There are differcnees in the way states approach security, but thesc variations are usually beter explanied by the specific conditions of the region rather than by culture. In other

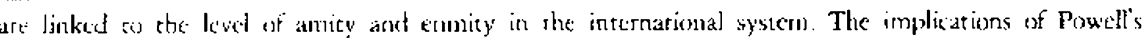
argument are of significancic lior the institurional aschitecturt and likely pattens of comperarion in the

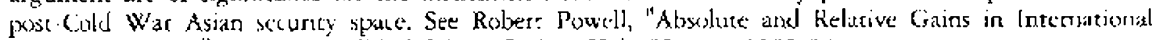
Relations Theory." Amertides Political Scienie Rewine, Vol. 85, pp. 1303-201.

Alexander Wende, "Collective ldersity Formation and the International State." Amersian Politial Scremet Retikz: Yol. 88, pp. 384-96i.

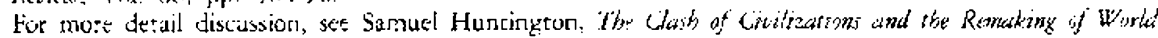
Orikr- (Nice Yurk: Sision and Shusrer, 1997)

Wende identipies three vartibles in the formation of collective identity; structural contexts, sstemic proctsbes, and srancegis, pratuet. The cumbinarion of these these variables with ane another promote colleccive identity formation asd povide as imfortant foundation for mutritateral institutions by increasing the whllagness to at on generalized principles of cunduct and diftuse reciprocity. Sec Alexander Wendt. "Coiberive haterity formation and the Inrernational state." 
words, the problem has to do with the security of Asia as a region connected to the international security environment, not Asian security based on cultural differences.

Alex Inkeles has some advice on this debate. He has called on the increasing convergence of modern or modernizing societies. ${ }^{27}$ Inkeles recognizes the continuing divergences in the developnent of modern societies and does not necessarily contradict. Huncington's emphasis is un the persistent differcnces across "civilizations. "Y'et, he has robustly dexumented many striking similaritics between muxtern socictics in terms of not only technology, organizational differentiation, and specialization, but also the nature of education, stratificatioti, and personality pattems. Moreover, inkeles' picture of converging interconnected modern societies meshes with Hobsbawm's point that "nationalism, however inescapable, is simply no longer historical force it was in the era of between the French Revolution and the end of imperialist colonialism after WWH."2.8

\section{THE U.S. ROLE IN ASIA}

Some may disagree with the argument that economic and nulitary dimensions of security are interwined in Asia. This prescription should not be taken to mean that all aspects of the region's security would be affected by the economic chass. Supporting this view, the security situation in the region's purential flashpoints, such as the Kortan peninsula, has not changed significantly as a result of the recent financial crisis. This is true because of another characteristic feature of Asian security: The L.S. is still a predominant regional power.

In Asia, bilateral relationships are the mose conspicuous than any other region in the world. All the powers in the region have been particularly energetic in reanimating existing ties or engaging high profile personal diplomacy in order to improve relations. The United States is very likely to lead bilateral relationshigs in Asia, and this trernd will conrinue into the next century. Despite Asianization and vastly divergent interests across Asian countries, one common view that seems to be shared by many of the regional states is that the Linited States' security commitment is the indispensable anchor for East Asian security. To say the least, an abrupt and large-scale American withdrawal woukl lave a powcr vacuum at which no other power would be able to fill without any profoutedly destabilizing conscoucnes.

The Clinton administration's defetse report entitled, "Linited States Security Strategy" for the East Asia-Pacitic Region," committed Washington to maintain the current force levels of about 100,000 troops in the East Asian region as a parc of "a strategy based on American leadership," which was designed "to enable the Li.S. to deal with two major regional conflicts nearly simultaneously."29 Entering the new century, there are no signs of any teversals or significant modifications of the U.S. policy; and the U.S.

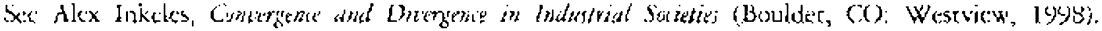

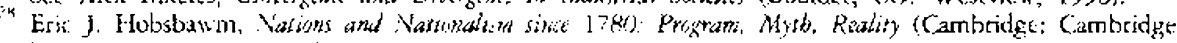
liuiv. Hress, (9) 2), ir. l(y).

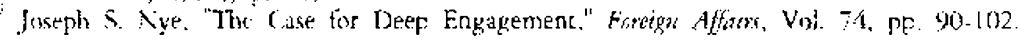


still scems determined to maintain its hegemonic position in the post-Cold War world in general, Asia in particular. In the case of Iraq or Kosovo, the U.S. foreign policy of engagement is based on a multilateral settlement, whereas in the case of Asia, such as China or North Korea, it is based on a bilateral setclement.

Indeed, America is ideally situated to play the role of Asian balancer. It is feared less than any other great power because it is geographically scparated from Asia by the Pacific Ocean, It has no territorial disputes with any Asian rations, and has bilateral alliances with four Asian nations that have freely chosen to align with it. The U.S. also possesses the economic and military power to underwrite a regional balance of power.

Unquestionably, the end of the Cold War provided the United States with a unique opportunity to reassess its role in the East Asia and in the world as well. For nearly five decades, it acted more like an empire than a republic, creating a global network of clitrit states, cstablishing hundreds of military installations around the world, conscripting yourgy men to staff these advanced outposts and fight in distant wars, and spending hundreds of billions of dollars annually on the military. 30 The justification for this interventionist strategy so unlike to the original American design was the threat of totalitarian communism. With that threat gone in the now millennium, the United Srates should return to its roots, rather than look for another convenient enemy.

the LiS., therefore, is about to encounter new problems with the posr-Cold War Asia. 'The main problem is sot to bortuw Oran Yong's and Joscph Nye's terminology, a structural one tesulting from a decline of its "hatd" milicary or cconsmic power, but an entrepreneurial and;or incellectual one reflecting inadeculacy in the exercise of "soft" puwer. 1 "The problem is closely telated to the "inward-looking" tendency and scarcity of Asian affairs expertise in the recent U.S. administrations. It may not be any easier to solve a soft-power froblem that to solve a hard-power problem. However, withour solving the problem, the L.S. is likcly to fail to continuc to play as critical and effective a role in shaping the security environment of post-Cold Wax Asia as it played in defining that of the region during the Cold War era.

In particular, the L.S. role in Asia is embodied by its relations to China and Japan. In East Asia, the common pivor of this regional sccurity complex is China. China is directly or indirectly involved in almost all of the most pressing security issues in the region. The avoidance of an unnecessary confrontation with China is more essential to the future L.S. role in Asta than any other subject. China boes not see itself as an aggressive power. Some niay say that China's ruthlessness, even at the cost of damaging its reputation and conomic interests, has been evident in handling of the takeover of Hong Kong and determination to acquire islands in the South China Sea. China feels it is fully within its rights to change the bumiliated territorial map, even though most

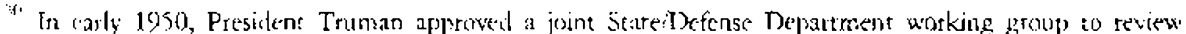
the narion's security policy. The rexult was Nix. Memorandum 68. which propused a massive consentional

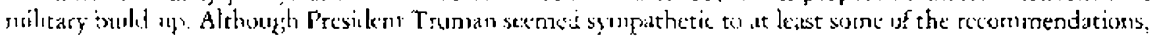
he deferevi action and ordered further study of the issuc. It was North Koreas invasion of South Kurea

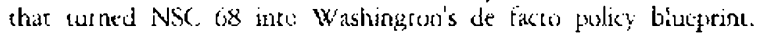

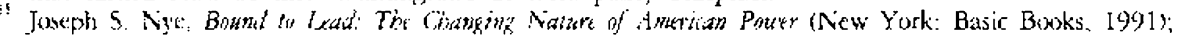
Oris R. Young, "Political Leaderstup and Regine Formation: On the Development of Inscicucions in

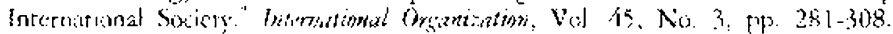


orher councries view such an action as aggressive and dangerous. In the debate between the pro-contairment and the pro-engagement schools of thought regarding China, it currently favors the latter group. 32 The advocates of concainment policy have capcured most of the headlines, but those who advocate engagement policy have made the stronger case.

Policymakcrs in Washington seem to understand that world peace in the next century will depand largely upon whether the increasing intercourse berween China and the Lnited States will lead to a constructive confluence of impulses, or a disastrous collision of interests. China is a revisionist power, but, for the foresecable future, it will seek to maintain the status quo ${ }^{3 j}$ and so should the United States. This proposition has clearly been proven in the case of the Korean peninsula, in which the Chinese position toward North Korea is somewhat advantageous to the South. 3.t The relations to China should be neither historically predetcrmined nor dependent on the frightening accideratal events imagined by some of the pessimists. Is will he decided by the usual historical mixcure of likely trends and deliberate human efforts to shape them. Therefore, wisdom on both sides of the Pacific can play a role.

In 1942, the Ming court left Nanking for the northern capital. It was a sensible military decision, bringing the government closer to the perennially-threatened Mongolian borders. Yet, it was also a decisive moment in history. China was turning its back on the sea coasts and retreating into a landlocked tmpire. It was against the possibility of maritime trade (spening by its ocean ships and was upting for an cconomy based on agriculture. Buried in this practical decision, if one wants to be fanciful, was Chinas isclation, its decline in the nineteenth century and the troubles that it brought. Thus, to China, the belief that it must right the wrongs of the humiliating history that began during this time is the main reason why the country does not see utself as an aggressive power.

At the same time, for East Asians, the lingering uncertatutics about the future of Japan werc also troublesome. All of the East Asian countries, except for Thailand, had lived under the disastrous Japanese-dominated East Asian Co-prosperity Sphere in the 1930 and 1940s. Unlike many in the West and in Japan who have come to see Japan as a reformed militarist nation, and a "civił power," many East Asians still view Japan

\footnotetext{
Adwocates of combainmon: policy forese the rise of a belligerent wwer, a process that will ineviably

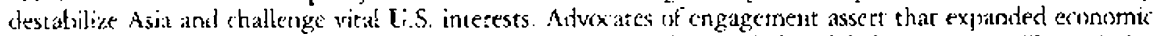
relations and official dialogues on security issues, humar rights, and the global commons will maximize the prospece in which Chisa will use its peswer in a manter conducive to L.S. interests. Sax Richard Bernstein and Ross H. Afunro, "China I: the Coming Conflice with America." Foreign Affarrs (MariApr

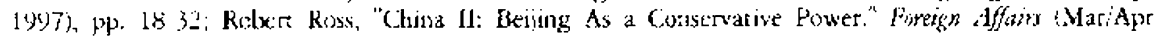
$19(9), 1), 33-41$.

i) The strixing cuse to this conservative trend is the Spratiy lsiands. Since the mid-1970s, Chua has buen reying co dininish the impart of the Sosth China Sea territorial disputes on ies relations with the conneriess in the ASE.AN. But it is roo carly to say whether thas incident reflects a new trend in Chinese policy w in briest digression designest to derer widespread land seizure in Sourh Asia.

if Cha has successfully shown how eticiently Gouth Korean govcoment has engaged China since hate 1980s. He evaluates the South Koreins Nuripolitiz to the deyres of sonewhere berween "minimal success"-tormal suppor: of North Kore:t and de facto tecognirion of Siuth Kisreal-and "vety successful"-discoulrage North Korean provication and aggession. Sec, Victor D. Cha, "Engaging Chína: Seoul-Beijing Detente and

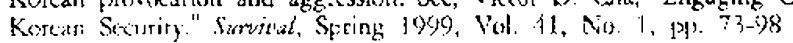


wich varying degrees of suspicion in terms of its milicaristic past. In ocher words, unlike those in the West who believe the Japanese militaristic culture of "sword" has given way to a pacific culture of "chrysanthemum," many East Asians see the revival of militarism as, by no means, a foregone scenario of the future Japan. 35

A concern about Japan becomes more significant with the consideration of Korean security. The security of Korea has long been a matter of substantial importance to Japa, not just for military reasens, but also for a full tange of political, economic, and cultural considerations. The security of Korea is vital to Japan's own security because the renewal of conflict in Korea would be perceived to have a more serious impact on Japan than any other conflicts that might occur in Asia. In view of the existing security artangements with the U.S., Japan woukd be drawn into the Korean conflict, either directly or indirectly. Furthermore, in vicw of the two Korcas' existing ties with their patrons, such a conflict could escalate into a major nuclear confrontation imperiling Japan's security. For thesc reasons, Japanese leaders from time to time bave believed that the best policy was to promore a "peaceful coexistence" berween South and North Korea by encouraging them to expand the scope of their contacts and dialogue.

Therefore, it would be fair to say that Japan is worried abour the instability arising from North Korea's solation and appears to reluctanty accept the division of Korea. Although Japan, through its policy statements, asserts its support for Korean reundification by peaceful means, a unified Korea would present some difficulties to Japan. First, in the long term, a unified Korea could emerge as a stronger regional competitor. Second, reunification could see the eventual departure of U.S. forces from the Korean peninsula. leaving Japan as the only country with a U.S. military base in East Asia. Finally, a unified Korea could pursue cooperation with China and Russia in order to balance Japan's economic superpower status.

\section{UPDATING KOREA-U.S. REIATIONS: A NEW ALLIANCE IN THE NEW ERA}

In many cases, alliance theory centers on the International Relations studies. ${ }^{36}$ If the initial conditions under which an alliance produces changes and these changes generatc divergenec in the security conceptions of the participants, then the likelihood of alliance termination is grtater. On the other hand, if such changes continue to give rise to convergent concejtions of security, then the basis for alliance perpecuation exists. Within this vein, the most important issue in Korea-U.S. relacions is whether the United Stares would maintain ground forces in South Korea with the disappearance of "Sovietology"

\footnotetext{
is For views on mo militaristic danger in the Japanese buture, see Peter J. Katzensiein and Nobun Okawara, "Japan's National Security: Structures, Norms, and Policies," Intematimal Sewwity (Spring 1993), Vol. 17, Nic. 4, pp. 8. -118 ; Thosnas U. Berger. "From Sword co (hrysanthemum: Japan's Culture of Anti-Militarism." intonational Sezirity (Spring 1933). vol. 17, No. 4. pp. 119-50.

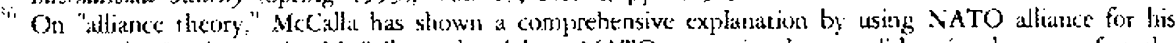
case study. In the sridly. MCCalla explored how NATO expansion has a solid rationile eren after the end of conmunist thecat. Sec Rohert McCalla, "NATO's persistence atter the Cold War." Internatynat Oysomization \{Suninee 19y5\}, Vol. 50. No. 3, pp. 4t5-75.
} 
and South Korea's successtil Nordpalitik with Beijing and Moscow. This is a question for new configuration of the Korea-L.S. alliance theory.

The Mutual Defense Treaty between South Korea and the U.S. was created in a different cra. Now the Cold War has ended, hegemonic communism has collapsed, and allied states have prosperod. In fact, recent events have rendered every assumption obsolete chat underlined Washingtori's commitment to the Sourh. ${ }^{3-}$ With these changes in the intermational covironment, America's defense commitments should change as woll. By the 1980s, Scoul outstripped its northern rival Pyongyang financially, technologically, and diplomatically. Seoul had a bigger population, greater access to foreign markets, and the ability to outspend militarily. By the early 1990s, even the North's allies were changing sides, as both the Soviec Union and China recognized Scoul. Moscow is now shipping anms to the South to help pay off its debts. U.S. officials, nevertheless, act as if nothing has changed since 1953. According to the Department of Defense, the I:S.-ROK alliance "is a vital component in our national objective of supporting and promuting democracy." 3 s

Some may argue that the enduring U.S. presence of ground forces in ever-expanding NATO provides a model for what is likely to happen in Northeast Asia following Korean unification. This would be a mistake. Russia is not China, and compared to China, Russia's concern over changes in the surroumling political geography appears chaotic and hadly managed. Cnlike NATO expansion, if the Korea-U.S. Mutual Security Treatry is extended to a unified Korea, there would be no buffer states separating the United States and China. Beijing could quictly let it be known that it did not wish to have the $\mathrm{L}$.S. remain in Korea or would prefer some reduction in their presence. One meaningful option for the L.S. is to gradually transform the treaty with South Kored from une seructured on land forces to one on naval forces. This would conform to South Korea's ow't expanding fleet, satisfy the need to reduce highly visible bases on the peninsulit, and ameliorate any Japancse concerns about the South Korean navy ${ }^{\text {ig }}$

Whatever specific policy oprions are to be adapted, three traditional buc newly configured L.S. interests exist with Korea. First is the broader U.S. interests in fostering the spread of market-oriented sconomies and democtatic political systems. 'This interest is rooted in the American beliel, generally confirmed by history, that an open, democratic workd is a safer, secure, and more prosperous world, for the U.S. and the world at large. Active and susrained Li.S. involvememt in Korea furthers this interest, as South Korea's progress roward a more democsatic polity and open economy testifies. The L.S. objective of supporting Korean unification essentially on Seoul's terms might also further the spread

In general, specialists an the Korean peninsula in the L.S. suggesr mare rodest L.S. role wh the regrion.

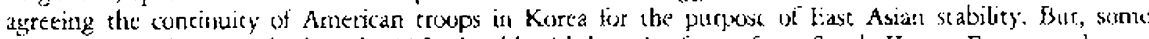
aggressive scholar interads that the li.5. should withdraw its forces from South Kurea: For example, see

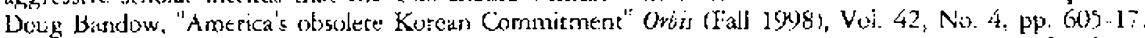

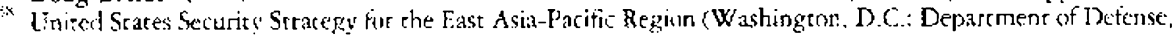
Feb. 1905). p. !i)

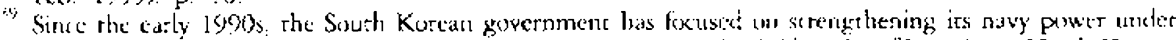

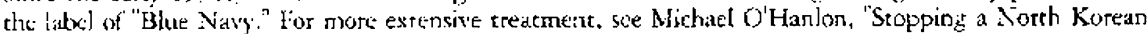

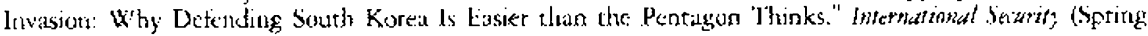
$1998)$, rol. 22, No 4, pp. !35.70. 
of democratization and market-oriented economies. Together these factors have underpinned support the U.S. to play a sustained role in Korean security. The mixture of economic and military dimensions of security, which is the very nature of Asian securiry, is prototypical with these interests.

Second, in the short to medium-cerm, Secul feels that the threat of the North attack on the South remains high due to internal political imperatives which may arise in the North. South Korea also tears that North Korea, in the face of declining military strength, mighe risk a strike before the balance of military strength turned too far against the Nurth. The U.S. security guarantee is a deterrent which the South Korcan military cannot match, no macrer what the attack, even if the ROK successfully blunted it. This would devastate South Korea and destroy the economic and political achievements of the past five decades.

Lastly, South Korean policymakers do recognize that in the long term, their nation will remain surrounded by powerful and potcntially hostile states-Japan, China, and Russia. South Korea will probably never possess the economic, political, or military clout of these nations. A security link to a powerful, friendly, but distane state with vital interests in the region, sucl as the UJ.S., enhances Souch Korea's strategic position significantly. to

Thus, to keep these interests, it is necessary that updating the Korea-U.S. relations should start from the wo important approaches to the altiance countries: the differences in security conception of the two countries and the preparation of each state's visions for unification. Throughout the Cold W'ar, a precarious but stable peace had existed on the Korean peninsula 4 i However, over the past several years, growing tensions in the alliance lave become apparent. This is due to the difference in the underlying conception of security, which has become more critical with the Cold War being over. In the Korea-U.S. case, a traying of relations on the surface may stem from disagreements over specilic policies toward the North, but the primaty cause of the friction is the increasingly diverigent definitions of security between the two allies. Based on the two traditional IR (International Relations: theories, realism and liberalism, Cha rries to explain the two countries' different perceptions on securicy and engaging policies to North Korea as its results. ${ }^{42}$ His work makes full sense since an ambiguous coexistence between the Cold War ideology and post-Cold War ideology is lingering uniquely in the Korean peninsula.

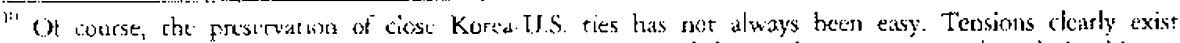
in Korea-U.S. rélations tudaf; the ineritable consequence of the need to restructure the reiationship on a more equal basis. The Korta-U.S. ccomennc iclacionship, for exarnple, has become a source of tecosiun which could sour greneral hilateral celations, and. Seoul has been wary of effors by the U.S. co escablish links with the DPRK. However, this does not necessarity mean a real conflict. The assertion of Korea indepcrufence and narional identicy is noe incompatible with Korea's friendship with the U.S. There is no fundumencal ionflict letween the swo nations. Inderd, the U.S. and South Korea will continue to share critical scrategic, ecomomic. ard policical intercosts

"Pirk has explained this atnbigunis srability by a concept of the two conelicring triangles; Moscow and Beilitg with Pyongyang. and Washongton and Tokgo with Seoul. According to him, with the Cokd War ower, there is oo longer a bifolas system that guarantees peace and stability in Northease Asia. See long W'han Park. "The Washington-Sooul-Pymgyang 'Trisugle." Tong Whan Park, ed., The U.S. and

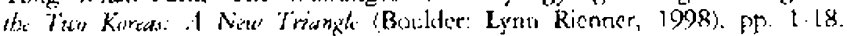

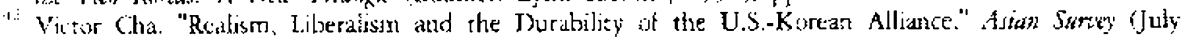

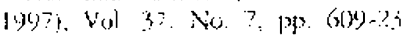


According to Cha, Washingron largely viewed its Korcan policy within the context of broader global geostrategic conceros, while Seoul viewed its L'S. policy within the narrow context of bilateral competition with the North. With the end of the Cold War, a gradual shift toward more pluralist conceptions of security by the U.S. has taken place. Nor that security and stability in a traditional realist sense have become irrelevant, but that greater emphasis can be placed on alternative means of achieving both. By contrast, South Korta's security conceptions have exhibited less change, remaining entrenched in classic realist mindsets. This is a very Cold War-obsessed mentality. 43 This divergence accounts for much of the current and potential difficulty in implementing the agreements. It also flags a deeper, more fundamental problem for the alliance to deal within the post-Cold War security in East Asia. This view should be remedied in the next century.

With regard to the U.S. rule in East Asia, North Korca annot bx omitted from the U.S. strategic configuration. The conventional outsiders' view of North Korea is that of a "rogue" regime, irrational, dangerous, provocative, and even aggressivc. But this view clearly requites a re-evaluation. Indeed, it is probably closer to the truth to assume the opposite about North Korea: it is a rational and defensive stace. ${ }^{44}$ Undoubtedly, North Korea would still like to rule the entire Korean peninsula, as every other sovereign state would so since the beginning of the Wescphalia era. Almost certainly, however, is knows that South Korean and U.S. military strength make that goal unachicvable and foolish to pursue.

It is also necessary to consider North Koren as a stare alienated from the U.S.-dominared international order. While the North Koreans, from our point of view, seem to be continually breaking the rules of the game, they are not a part of the game and have never accepted the rules in the perspective of the "West." ${ }^{\prime \prime}$ is The Kim Jong 1.1 regime, like its predecessor, Kim Il Sung's, has been a ruthless government that in many respects has donk its people terrible disscrvice. From the standpoint of international security, however, North korea is not Nazi Germany or even Iray. It is an alienated, defensive state facing possible extinction. Although North Korea is heavily armed, a war would only hasten its demise, contributing nothing to the solution of the serious problems the regime faces. North Korea is fully aware of this. The logic of the nuclear deal was in essence a quid pro quo: Pyongyang would trade its ulrimate insurance policy--its nuclear weapons program--for a new economic and political cngagement with the U.S., the ROK, and Japan. But,

l" As a typical example, to the lis., the Agred Framework (1994) on North Korean Nutlear project smarks a ule coward mare pluralist deticuition of secuticy in East Asia, while the South Korca remains embedded in classic realist conceptions of security to secure its advancageous initiatives through containing Nortl Korea.

1.1 Several scholats insist that Nurth Korean government be mukh mose rarionat than we understand: Among them, in particular, Shart Shija, accepting North Korea has changed its policies on economics, trade imf fercign relarions oser the years, argues that, not only incesnal evencs under the Kim Jong Il administration, but also external events play key coles in the tuture of North Korea. Sie Sharif Shuia, "Reforms and

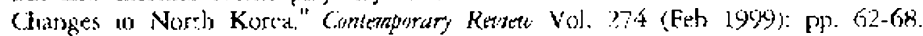

45 There are several cases to prove chis argument. For instances, DPRK is profoundly opposed ro America's ceinstitution at Japas as the regien's economic hegenon, and of course co the original division of the Korean peninsula and the escablishment of a South Korean government they believe could not survive withour American military backing. These positions are all possible on rhe rational and consistent DPRK's toreign :xlicy. 
ironically enough, the underlying assumption of the nuclear deal in the perspectives of the U.S. and South Korea was that is would catalyze the multi-faceted economic and political engagement of Pyongyang with the international community. 46

Based on this catculation, the most critical re-evaluation of current policies toward North Korta for the next time space is that policies toward North Korea have been mainly focused on the nonproliferation theory until today. But, it does not say anything about how a unified Korca would transform the strategic politics of East Asia in the next cenrury. 17 Nor can it rescribe how a failure to unify Korea might result from ourside powers actively working to maintain partition, perhaps using non-proliferation as a mask for a decidedly more geopolitical purpose. Indeed, unification would look fundamentally different to Seoul if outside powers had propped up a weak regime in the North for the indefinite furure as a way to restrict Seoul's own military and economic power.

\section{ASIAN WAY OF INSTITUTIONALIZATION}

\section{European Model in East Asia?}

As explained so tar, the end of the Cold War and the end of the world's fear for destruction have had an unexpected effect on Asian security. The above analysis leads us to identify four characteristic features of Asian security in the cwenty-first century: Asian countries' critical concerns on the power relations among their neighbors are as follows: unquestionably, how to continue economic prosperity in the region, then to transfer its positive effect into the military-political space is the key factor in the Asian security discourse; the U.S. continuous presence as a balancer is forcsecable; and Asian culture should not be blamed for the underdevelopinent of institutiondization. To launch a less confliting sccurity fratne among Asian countries in another time space, I suggest the Astan way of institutional interdependence.

What is the best way to ctevelop institutional interdependence among Asian countries? In Europe, there is an increasing identification of self-interests of each nation-state with collective incerests of Europe as a whole. In Europe, this tendency is manifested by the development of cooperative foderalism within the European political space occupied by the European Union. This same process is underdevcloped in Asia: Asia lacks not only an effective system of collective securiry or defense on par with NATO, but lacks the institutionalization of economic cooperation approaching the level achieved by the European Ĺmion.

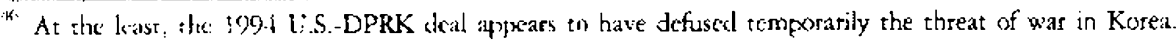
This is considered to be a major success by the L.S.

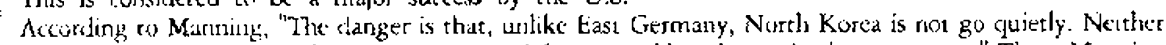
Seoul, W'ashingrun, nor Tokyo appear prepared tor any sudden change in the status quo." Then, Manning sugzests a suft landing and gradual reunification process within there stages: mulest confidence building measures, deeper economic invalvement, and confederation pengosal. See Robert Manning, "The United Srates and the Endgrame in Kurea: Assessment. Scenarios, and Implications." Asian Strrege (July 1997),

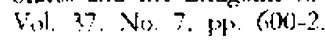


There are two reasons why the European model of institutionalization cannor be applicel to Asia withour some adjustments, let alone the cultural differences, or collective idencities. First, the Asian nation-states and the Furopean nation-states are at difference stages of evolution. The Europsan states are increasingly characcerized by an ecosion of sovereignty and growing economic interdependence and by the need of national authorities to consolidate and sustain internal power by increasing external cooperation. The progressive erosion of national sovercignty in Europe is the tesult of two tendencies: the voluntary transfer of sorereignty to international or supranational institutions to resolve outstanding conflicts between staces; $; 8$ and the progressive inivoluntary loss of sovereignty to the market mechanism and the subsequent efforts to recapture that sovereignty via membership in international institutions that facilitate multilateral governance and joint problem solving. Contrary to this European erend, the domestication of internarional politics has not progressed very far in Asjan countries. Consequently, the need for international inst itutions to resolve outstanding political-military conflicts or the interdependence dilenmas with in Asia have not been perceived as nccessary or usceful by the states of the region.

A second txplanation may be located in the context informing the calculus of state action. The Asian countries remain fixaterl with issues of territorial integrity and face acute territorial challenges. States remain unencumbered by norms against the use of the military instrument to resolve outstanding disputes among themselves and remain challenged in many cases by internal threats to its legirimacy. Therefore, among Asian countries, the issuc of trust still remains asleep. Thus, this external context should lead us to expect larriers of coopcration between the nations in the region. Motenver, the continued preoccupation with relative gains drives states to be less concerned with ensuring optimal outcomes within the region and more concerned with ensuring that cooperation does not lead to an actvantageous change in the hierarchy of regional power. Asian states remain defensively positional--states ate more concerned with their relative power position thars assuring cooperalive outcomes that maximize the absolute gains from coperation.

\section{East Asian Institutionalization}

My argument for the creation of any virtual institutions to deal with Asian security issues is the combining of neo-realist and neo-liberal visions for the Asian way of institurional interdependence. Neo-realists have tended to sce a return to multipolar power balancing. as a sort of asual pre-Cold Wat business. Neo-liberals see an urgene need for a new round of cooperat ive institution-building to prevent new conflicts emerging in an increasingly inrerdepentent world. Yet, in many ways, there are no fundamental differences between these two broad paradigms on security. Both assume that the pursuit of rational self-interest is the driving force of intertrational relations. Both focus primarily on state actors, and despite the interests of Kantian-inspired liberals in the inter-subjective or universal values of a global community, it is the nation-state, not some global collective security, that

in The typical example tor this case is that. the Eorsupean Coal and steel Community (FCSO) was the

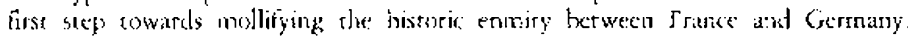


is to be secured from threars.

The prevaling discourses on regional securicy in Asia represent an intriguing atrempt to reconcite the basic assumptions of neo-realism and neo-liberalism outlined above with the notion of different Asian security culture. There appears to be no lack of "uncertainty"; the presence of a flash-pointing state like North Korea, the fears over the neo-nationalist ambitions of China which lay claims to much of the South China Sea, the lingering memorics of Japan's imperialist past, the unresolved territurial disputes, and the potitical instability in Russia and its former eastern republics are all commonly cited as potcntial security threats. In addition, many states in the region have been engaged in extensive milicary modernization programs, which have significantly lifecd the general level of defense spending. There is a widespread perception that the predominant post-Second World War American military presence may not be sustainable over the long cerm. l fowever. for the mument, the prevailing "uncertainty" and the realist abhorrence of a power vacuun provide the rationale for the continuous C.S. role as a balancer.

The most critical ispect in the Asian way of insticutionalization is associated with "sovercignty." It can be handled by combining multilateralism with bilateralism. We understand that multilateralism, as a form of relations between three or more states, is generally thought to be a cooperative mechanism for restraining self-interests of the states through agreed rules or shared beliefs. Sonetimes, the formal structure of a regime with norms, rules, and punishments for deviants may involve the surrendering of some powers of sovereign starehord. However, the case is somewhat different in Asia. Multilateralism is generally considered to be suppotting rather than replacing the predominant bilateral security arrangements among states in the region. Despite the criticisms for the failure of the United States to adapt its bilateral security treaties with regional states (Jupan, South Kurea, and the Philippines) to the post-Cold War environment, chesc treaties remain the dommant mechanisms for regional security. Various bilateral ereacies with the lnited Stutes have been reinvigorated in 1995 and 1996 with concerns over China's regional ambitions and inseability in Norch Korca. Japan itself has floured proposals for bilateral security dialogtic with the states of ASEAN, although the ASEAN response has been tentative due to their concerns of provoking China's regional sensibilities. For its part, China appears w be operatcing under the assumptions that policies of containment are falling into place, and as a result of this pressure, it has partly culcivated closer relations with Russia. These developments appear to have injecred a new dose of bilateralism into strategic plannitg which could seriously undermine even the limited ambitions of proponents of regional multilateralism. Therefore, the bilateral accomplishments and multilateral tasks by the L.S. acting as a balancer may be one of the most important features of the Asian way of inscitutionalization.

If the ASEAN Regional Forum (ARF) continues to be successful, it can set a good example to the "Asian way" of institurionatization. For example, the ARF official statements represent a blending of concerns with cooperative approaches to security first given by the CSCE (Council for Security ant Cueperation in Europe) and the values of an Asian Way. The statenaten from the seiond $\Lambda \mathrm{Rf}$ meeting in 1905, for example, "recognizes rhat the concept of comprehensive security inchudes not only military aspects but also 
political, economic, social and other issues." It also crutines a three-stage process for security dialoguc, namely, the promotion of confidence-building, development of preventive: diplomacy and elaboration of approaches to conflicts. And, following the ASEAN radition, the meeting endorses the principles of consensual decision-making. The various proposals for CBMs (Contidence Building Measures) and preventive diplomacy, which focus on transparency, a range of official dialogues on security planning, and the development of principles of dispute resolution, amount to regional adaptations of European and LN discourses on the subjert.

Finally, the tendency roward orthodoxy in regional security discourse is demonstrated in the process of the so-called, "track two" dialogue, which has become an important part of the ARF itself. Track two dialogues refer to the discussions of often sensitive security issues among governmental and non-governmental personnel with an understanding that they met in a strictly non official capacity. Some of the recommendations of such dialoguc may, however, serve as the foundation for later development of government poslicy. Some analysts argue that this process retlects in itself an Asian preference for informal policymaking merhods.

Noticeably, attention is directed toward adapting cooperative instieutions to the specific and different aspects of Asia. This might be called an "intersection of Western-style inscitution-building and Asian-style cthos-building." tends to assume that there is a discernible "Asian way" of security, fundamentally different from the West, which must be a part of any attempes to build a regional secturity community. In philosophical terms, it could be said that the liberal value of toleration meers halfway with the idea of an Asian way. It is perhaps a propitious example of what John Rawls refers to as a "shared basis of agreement among reasomable peoples."50

\section{CONCLUSION}

The term seizrity deserves the widest definition, and the sccurity and well-being of various countries have become highly interdependent. In Fast Asia, these include the increasing arms building, the regional financial crisis, the emergence of famine in North Korea, the humanitarian struggle in East Timor, and the issues of entangling sovereigntics surrounding China. All these happened or are happening in the time space at the start of the new millernium. In particular, if the Asian countrics' haze underlined the limitations of the sovercign states in dealing with the current economic hardships, then the economic: crisis was an eloguent statemene of the inevitability of regional interdependent security.

Korea represents one of the most typical Asian secutity concerns in the rwentieth century. The South Korean economy is the size of the economies of Malaysia, Indonesia, and Thailand combined. This made the relief operation organized by the International

"The term is wriginally from tivass, sec: P. Evans. "The Prosperes for Mutidateral Secusicy Cooperation

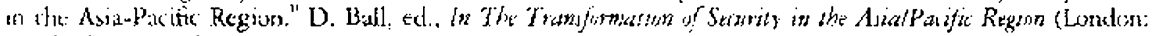
Frank Cass. 1096:

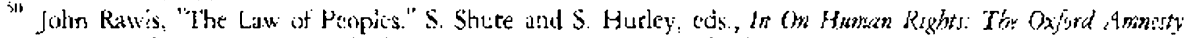

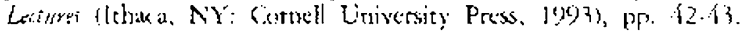


Wonetary Fund the largest in the region. At the same time, the country, at issue, is of particular interests because is is intertwined with interests of superpowers. This is the current circumstantial condition the Korean peninsula is confronted with at the beginning of the twenty-first century.

Throughout this paper, I have explained several important subjects regarding Asian sccuricy: the security complex of military-economic dimensions, the lesser development of insticutional multilateralisn in Asia, the never-ending U.S. presence in the region, and its ratation to a cricical flashpoint of Asian security, the Korean peninsula. Then, 1 proposed the Asiran way of liberal institutionalization in order to handle these security incricacies. In the next century, the nasure of Asian security will continue. Without a clear and comprehensive interpretation of those multiple spheres of security terrain in the region, the prevailing possimistic view will last even in the new time space.

Cieorge Orwell once said, "whorever controls the past will control the future." Even though history is not an infallible guide, it is the best we have. Yer, the problem is that with the removal of Soviet power and the relative reduction of the L.S. presence at hand, the scates of this region are, the first time in our modern history, facing the need to sort out their relations with each other largely frec from forcign presence that had dominated the area since che mid-nineteently century. Whereas the nineceenth century histery or the intcr-War pxriod history is a key lesson to the West, Asta doesn't have that kind of hiscory in order to learn from the past. We also know that bad analysis makes our prediction worse. This makes us realize how valuable the present is, ending the Cold War history and crtering the post-Cold War history.

\section{REFERENCES}

Bandow, Doug. 1998. "America's Obsolete Korean Commiment." Orbis 42(4): 605-17. Bernstein, Richard and Ross H. Muno. 1997. "China 1: the Coming Conflict with America." Foreign Affairs 75 (MariApr): $18-32$.

Betts, Richard. 1993/4. "Wealth, Power, and Instatility: East Asia and the Linited States after che Cold War." Intemationist Secarity 18(3): 3/-75.

Booth, Ken ed. 1998. Statecrafi and Security. The Cold War and Beymd. Cambridge: Cambridge University Press.

Braudel, Fernand. 1905. A Hislom of Cinilization. London: Penguin.

Butl, Hedley. 19?7. The Anarbsial Society'. New York: Columbia Iniversity Press,

Buzan, Barry. 1991. Pente. Slates: and Fear: The Natignal Security Problem in Intemational Relatians. Butilder: Lynne Rienzer.

1995. "The Pust-Cold War Asia-Pacific Security Order: Contlice or Cooperarion?"

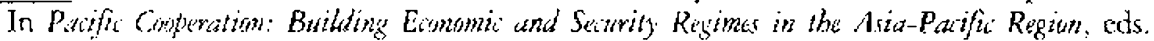
Andrew Maclntyre and John Ravenhill. Boulder: Westview Press.

Cha, Victor D. 1999. "Fngaging (hina: Seul-Beijing Detente and Korean Security:" Survinal (1) (1): 7398 .

1997. "Realism, Liberalism and the Duratility of the US-Korean Alliance." Asian Sitr(2) 37(7): $6(19)-2.3$.

Dupont, A. 1996. "Is there an isian Way." Survival 38: 13-33. 
Evarts, P. 1996. "The Prospects for Multilateral Security Coopcration in the Asia-Pacific Region." In The Transformation of Secwrit) in the AsialPasifu Region, ed. D. Ball. London: Frank Cass.

Eriedberg. Aaron. 1993\%:4. "Ripe for Rivalry: Prospects for Peace in a Multiple Asia," Intemational Security 18(3): $5-33$.

Funabashi, Y. 1994. "The Asianization of Asia." Forrign Affairs 72: 75-86.

Gilpin, Roberr. 1981. War and Changes in International Politics. Princeton: Princeton University Press.

Hobsbawm, Eric J. 1992. Natims and Nationalism. since 1780: Program. Myth. Reality. Cambridge: Cambridge University Press.

Huatington, Samuct. 1997. Tbe Clasb of Carilizations and the Rebinking of World Order. New York: Sinon and Shuster.

Inkeles, Alex, 1998. Canvergtote and Diverzence in Industrial Sacieties. Boulder: Westview.

Johnson, Charlmer. 1998. "Cold War Econonics Mele Asia." The Nation (February): 16-19.

Keotane, Robert O. 1984. After Hegemong: Conperation and Discord in the Warld Political Eornamy. Princeton: Princeton University Press.

Keohane, Robert O. and Joseph S. Nye. 1977. Pouser and Interdependence. Boston: Little Browis.

Keohane, Rohert O. and Lisa Martin. 1995. "The Promise of Irstitutional Theory." Intemational Securit) $20(1): 39-51$.

Kissinger, Henry. 1994. Diplomaty. New York: Simon and Schuster.

Krugman, Paul. 1995. "The Myth of Asia's Miracle." fiorvign Affoir. 73(6): 62-78.

Manning, Robxrt. 199?. "The United Stares and the Endgame in Korea; Assessment, Scenarios, and Implications." Arian Sumey 37(7): 597-616.

McCalla, Kobert. I9OS. "NATO's Persistence after the Cold W'ar." Intenational Organiation $50(3): 15-75$.

Mearsheimer, John. 1994/5. "The False Premise of Institutions." International Security 19(3): $5-49$.

Nye, Joseph S. 1495. "Tle Case for Deep Engagement." Forvign Affair 74: 90-102.

O'Fuanlon, Michael. 1998. "Stopping a North Korean Invasion: Why Defending South Kored [s Easier than the Pentagon Thinks." International Saturty 22(4): 135-70.

Park, Tong Whan, 1998. The US and the Tier Koreas: A Neu Trangle. Boulder: Lysn Riesnice.

Pollack, Junathan D. 1996. "Pacific Insecurity: Emerging threats to stability in East Asia." Curent 384 (July-August): $23-27$.

Puwcll, Rubert. 1991. "Absolute and Relative Gains in Juternatiunal Relations Theory." Amerian Polisical Srience Revieu: 85: 1303-20.

Ross, Robert. 1997. "China II: Beijing As a Conservative Power." Foretgn Affairs 75 (Mar/Apr): $33-41$

Shuja, Sharif. 1999. "Rcfurms and Changes in North Kotea." Contemborary Rewiew 274: 62-68.

Shute, S and S. Hurley, eds. 1993. On Homan Rights: The Oxford Amnesty Rectures. Ithaca: Cornell University Press.

Wacver. Ole, td. 1993. Identity. Migration and she New Security Agenda in Eurppe. Londun: Pinter Publishers.

Wade, Robett. 1996. "Japan, the World Bank, and the Att of Paradigm Maintenance: The East Asian Mitacle in Policical Perspective." Niw Left Rniew 217: 3-36.

Waltz, Kenneth, 1979). Thesny of Intemational Politici. Reating, MA: Addison-Wesley.

W'endt, Alcxander. 1994. "Collective Identity Formation and the International State." American Paltical Siretic Raviez' 88: 384-96.

Young, Oran R. 1990. "Political Leadership and Regime Fomation: On the Development of Institutions in International Sociery." International Oryantation 45(3): 281-308. 